\title{
Tempo e História em Santo Agostinho
}

\author{
Time and History by St. Augustine
}

José Nicolao Julião ${ }^{1}$

Resumo: O objetivo principal deste ensaio é o de apresentar como se constituiu um modelo teológico da filosofia da história em Santo Agostinho que tem a Providência divina como o seu princípio de determinação, o tempo linear sucessivo como a sua forma de desenvolvimento e a salvação como a sua finalidade. Para o proposto, focamos nossa análise em A Cidade de Deus, especialmente, nos livros de XI a XXII e nas Confissões, no livro XI, acerca do tempo. Apresentamos a seguinte estratégia expositiva em nossa interpretação: $1^{\circ}$, analisamos o entendimento que Agostinho tem do conceito de tempo, como sentido interno na alma e sucessivo em sua relação com a eternidade, exposto no livro XI das Confissões, para melhor, compreendermos a ideia de tempo linear progressivo projetada em $A$ Cidade de Deus como fio condutor da história humana; $2^{\circ}$, nós interpretamos a distinção estabelecida pelo autor na origem, entre duas cidades, a de Deus e a terrena, enfatizando que há uma tensão entre ambas, entre o bem e o mal, em decorrência do livre-arbítrio humano, que faz com que história se desenvolva. $3^{\circ}$, por fim, consideramos o processo de desenvolvimento e os fins das duas cidades, narrada na perspectiva bíblica da ação dos grandes patriarcas em suas relações de obediência e desobediência a Deus, ligando à história progressiva da salvação.

Palavras-chave: providência, tempo, história, progresso, salvação

\begin{abstract}
The purpose of this essay is to present how a theological model of the philosophy of history was constituted in St. Augustine which has Divine Providence as its principle of determination, successive linear time as its form of development and salvation as its goal. For the purpose, we focus our analysis on The City of God, especially in the books of XI to XXII and the Confessions in Book XI, about time. We present the following expository strategy in our interpretation: $1^{\text {st }}$., we analyze Agostinho's understanding of the concept of time, as an internal sense in the soul and successive in its relation to eternity, set forth in Book XI of Confessions, to better understand the idea progressive linear time projected in The City of God as the guiding thread of human history; $2^{\text {nd }}$., we interpret the distinction established by the author at the origin, between two cities, that of God and the earthly one, emphasizing that there is a tension between the two, between good and evil, as a result of human free will, which may history unfold. $3^{\text {rd }}$., we consider the process of development and the ends of the two cities, narrated in the biblical perspective of the action of the great patriarchs in their relations of obedience and disobedience to God, linking to the progressive history of salvation.
\end{abstract}

Key-word: providence, time, history, progress, salvation

${ }^{1}$ Professor Titular - UFRRJ/ICHS/Dep. FILOSOFIA. jnicolao@ufrrj.br, Pesquisador do CNPq. 


\section{Introdução}

A cunhagem da terminologia Filosofia da História, embora, só tenha aparecido em textos filosóficos a partir do séc. XVIII - o que faz certos intérpretes acharem anacrônico o emprego da nomenclatura a Santo Agostinho ${ }^{2}$-, isto, não nos autoriza, entretanto, a afirmarmos que não houve, antes, reflexão sobre a história. Já na Antiguidade, podemos falar de uma narrativa reflexiva sobre a história, sendo desprovida, no entanto, de reflexão filosófica, propriamente. Seguindo nesta mesma linha de raciocínio, talvez, possamos dizer o mesmo sobre a filosofia cristã antiga e, consequentemente, da Idade Média, que não houve reflexão filosófica, propriamente dita, sobre a história. A reflexão teológica cristã, basicamente, é aquela que explica os eventos históricos ordenados pela atividade de uma autoridade externa, nomeadamente, a providência divina que conduz o processo da destinação humana, como o seu motor propulsor, orientando a sua finalidade para a salvação. Por este prisma, a reflexão teológica cristã sobre a história marcou de forma decisiva todo o período, desde antes dos séculos IV e V, aqueles de Agostinho, até a primeira metade do séc. XVIII, que ainda, predominantemente, preservou a providência divina como princípio regulador da história; como exemplos caudatários deste desfecho, podemos destacar Bossuet e Vico. E isso se deve, essencialmente, a forte influência dominante do cristianismo, em sua versão agostiniana sobre a cultura ocidental.

Para compreendermos, portanto, o processo histórico narrado pelo Santo Doutor, em sua teologia da história, nós partimos, em nossa interpretação, de quatro pressupostos basilares: o primeiro, nós não iremos demonstrar, pois se trata de um pressuposto incondicional básico, segundo o qual há uma posição dogmática, teleológica, fundamentada na fé, que garante a priori uma ordinatio Dei, e que, por isso, não precisa de prova racional $^{3}$, por mais que este pressuposto, aparentemente, pareça ambíguo, devido à forma como Deus se manifesta na história, ao mesmo

\footnotetext{
${ }^{2}$ Cf. por exemplo, BITTNER, R. “Augustine's Philosophy of History”. In G. B. Matthews (ed.), The Augustinian Tradition, Philosophical Traditions, Berkeley: University of California Press, 1999, p. 345.

${ }^{3}$ Em Santo Agostinho, não existem provas formais para demonstrar a existência de Deus. Embora toda a sua obra seja uma espécie de justificativa da Sua existência. Cf., por exemplo, Comentário aos Salmos, v. II. 74, 9; A Trindade, $\mathrm{XV}, 4,6$; em Contra os Acadêmicos, é dito que na mente humana estão presentes verdades eternas, universais e necessárias que uma mente mutável e contingente não pode produzir, disso se deduz que Deus existe como razão suficiente das coisas. (Cf. livro I, cap. 3; Livro III, Cap. 28, 42.)
} 
tempo, "tão escondido e tão presente"; segundo, o estabelecimento de uma distinção, na origem, entre as duas cidades, a de Deus e a terrena, destacando que há uma tensão entre ambas, devido ao livre-arbítrio humano; terceiro, o processo de desenvolvimento e os fins das duas cidades, narrados na perspectiva bíblica da ação dos grandes patriarcas em suas relações de obediência e desobediência a Deus, ligando à história progressiva da salvação; quarto, uma concepção linear sucessiva, porém tensa, do tempo que o filósofo traz de reflexões anteriores à obra A Cidade de Deus, sobretudo, das Confissões, escrito no qual ele refletiu sobre o seu próprio processo de conversão que pode ser considerado uma teologia do eu, e que é fundamental para se compreender o processo progressivo da sua teologia da história da salvação.

Podemos expressar a relação desses pressupostos na seguinte formulação: é a partir do tempo linear progressivo, compreendido, primeiramente, no interior da alma, que Agostinho projetará à temporalidade progressiva histórica que se move devido a uma relação conflitante de tensão entre bem e mal, decorrente do livre-arbítrio humano, que incide sobre esta ou aquela cidade, qualificando-a como sendo a de Deus ou a dos ímpios, respectivamente, a fim, de realizar, no termino deste processo histórico, uma paz perpétua, justificando, assim, a presença de Deus atuando sobre a salvação da humanidade. Para o proposto, focaremos a nossa análise, principalmente, nos livros de XI a XXII d'A Cidade de Deus e no livro XI das Confissões, recorrendo a outros escritos apenas, circunstancialmente, para reforçar ou contrapor às teses apresentadas. Comecemos a nossa análise pelo último destes pressupostos.

\section{A compreensão linear e tensa do tempo em as Confissões e o progresso histórico para salvação}

É propalada a ideia de que Agostinho, em as Confissões (397-398), ao refletir sobre si mesmo, em seu processo de autoconversão ao cristianismo e consequentemente de sua autossalvação, teria elaborado uma teologia do eu e que, em $A$ Cidade de Deus, na qual ele narra uma teologia da história, estaria em uma posição diametralmente oposta à obra de juventude. Embora não seja nossa intenção, neste estudo, demonstrar de forma fecunda que haja uma pertinência ou incongruência entre essas 
obras, pois esta questão, por si só, já nos levaria a outro estudo, nós defendemos a tese da congruência entre ambas que também é de grande difusão entre os intérpretes do Santo Doutor, focando especialmente o conceito de tempo. De imediato, podemos afirmar que tanto em uma obra quanto em outra tratam do processo de desenvolvimento da salvação. Só que, a primeira trata do indivíduo em sua história existencial da salvação, enquanto que a segunda trata do indivíduo na história universal, o que é o mesmo que dizer, em ambas, se trata da passagem do individuo da temporalidade para a eternidade. Entretanto, como nós já frisamos, este não é de imediato o nosso foco mais urgente, ainda que a questão também seja contemplada em nossa análise, o que queremos apresentar por ora é: como a compreensão de tempo enquanto forma unidimensional do sentido interno, ou melhor, que ocorre no interior da alma - ou da mente -, estabelecida nas Confissões é um dos pressupostos necessários, em nossa hipótese hermenêutica, para se entender a reflexão teológica de Agostinho sobre a sua noção prematura de progresso apresentada em $A$ Cidade de Deus. A sua concepção de tempo lhe possibilitará projetar uma visão de percurso linear progressivo, bastante peculiar, sobre a história em A Cidade de Deus, assentada no futuro como horizonte temporal de uma meta predeterminada da salvação. No entanto, a sua compreensão linear do tempo, em as Confissões, não pode ser confundida com a ideia de tempo linear e cronológico, pois o contraste tenso entre o tempo e a eternidade provoca o confessar das diversas intensidades temporais, permitindo assim um aprofundamento da temporalidade humana.

Em as Confissões, no livro XI, é apresentada aquela que talvez tenha sido, do ponto de vista filosófico - sem queremos minimizar a importância das suas teorias sobre a memória, o amor e o livre-arbítrio - a maior contribuição conceitual do seu autor para história da filosofia, a sua noção de tempo. Sabemos que, de modo geral, a concepção agostiniana de tempo contrasta com a visão clássica grega ${ }^{4}$, compreendida como ciclo, uma vez que o cosmo era concebido como eterno em si mesmo, sempre se repetindo. Santo Agostinho, seguindo à tradição judaico-cristã - sem, contudo, abandoar certa discussão que havia se disseminado a partir de

\footnotetext{
${ }^{4}$ Embora Santo Agostinho, assim como a visão genérica de mundo cristã rejeitem a noção cíclica clássica de tempo, o conceito de tempo relacionado ao movimento e à mudança é uma invenção de Aristóteles, Física, IV, 10-14, de 217 b 1, 30 à 224 a 1, 15. Mas especificamente, em IV, 11, 220 a: "o tempo é o número do movimento segundo o antes e o depois”. De certo modo, com essa interdefinição entre movimento e tempo, Aristóteles inaugura uma discussão que permeará o Estoicismo, o Neoplatonismo e adentrará a Idade Média. Cf. sobre LÖWITH. Op. cit., p. 162-3.
} 
Aristóteles - tinha em oposição à visão circular clássica, uma ideia do tempo sucessivo, não cronológico, contrastando com a eternidade atemporal. A reflexão do nosso filósofo, sobre o tempo, tem como ponto de partida a sua exegese do livro Gênesis, do Antigo Testamento, acerca da existência de Deus e da Sua criação do Céu e da Terra e a discussão disseminada a partir de Aristóteles sobre a relação em entre o tempo e a mudança transmitida ao Estoicismo e ao Neoplatonismo. A questão central sobre o tempo no Livro XI das Confissões é apresentado nos capítulos de 1 a 28. Os capítulos 29, 30 e 31 são mais genéricos e fogem do tema central deste livro, mas são superimportantes na economia do texto da obra como um todo, eles discorrem sobre a unidade do ser individual, o para além dos tempos e sobre se Deus conhece de modo diferente das criaturas. Concisamente, podemos compreender o essencial sobre o tempo através de uma grande divisão entre dois eixos, nos quais, dos capítulos de 1 a 13, Agostinho prepara o questionamento da contraposição tensa entre o tempo e a eternidade e nos capítulos de 14 a $28^{5}$, ele desenvolve os argumentos centrais constitutivos da teoria do tempo propriamente dita. Portanto, neste pequeno tratado sobre o tempo apresentado no Livro XI das Confissões, Agostinho apresenta todos os impasses e dificuldades para se pensar o tempo: o impasse quanto à ação laboriosa para explicar o que vem a ser a sua essência e a dificuldade lógica insuperável para apreender e traduzir em palavras a sua natureza de ser e não-ser.

No parágrafo de abertura ao capítulo 1, ele já apresenta todos os impasses decorrentes da contraposição entre a eternidade divina e a temporalidade humana. É esta contraposição que move toda a primeira parte do Livro XI e é conduzida pela seguinte questão: se Deus vê ou não as coisas que passam no tempo? Porque sendo Ele eterno, consequentemente, recusaria a sequência temporal humana, comprometendo, prima facie, a confissão da criatura para com Ele, que devido às Suas onipotência e onipresença já saberia, de antemão, tudo o que a criatura Lhe confessará. Entretanto, a conversa com Deus em forma de confissão não tem o caráter de ser uma comunicação de acontecimentos, senão, o de despertar na criatura o seu amor para com o Criador. O contraste tempo-eternidade provoca o confessar das diversas

\footnotetext{
${ }^{5}$ Esses capítulos podem, por sua vez, ser divididos de 14 a 20 que tratam da interioridade do tempo e da sua mensurabilidade na alma e 21 a 28 sobre a essência do tempo.
} 
intensidades temporais, permitindo assim um aprofundamento da temporalidade humana, em níveis sempre mais estendidos, contrapondo a ideia de um tempo linear cronológico.

No capítulo 4, ao interpretar o primeiro verso do Gênesis, Agostinho chama atenção de que o céu e a terra foram criados e as características dessa criação são as mudanças e variações que, portanto, são indicadores de movimento que, por sua vez, só ocorre no tempo. Nesse capítulo, ainda, é mencionado, introdutoriamente, as três dimensões do tempo linear sucessivo - que serão mais desenvolvidas no decorrer do livro $\mathrm{XI}$ - que se referem à criação, o antes (prior), o agora (nunc) e o depois (post) que só ocorrem no âmbito do que é criado, pois o Criador é sempre eterno e, consequentemente, antes de tudo. Fica estabelecido, nesta parte da obra, então um princípio fundamental da metodologia agostiniana que a dedução do que é criado pelo não criado, isto é, O Criador. Depois de tratar nos capítulos 5 e 6 da questão do Verbo criador - acompanhando o Gênesis -, Agostinho, no capítulo 7, irá especificar a sua natureza que não é temporal, mas eviterna, ou seja, sem começo e sem fim. O tempo, deste modo, será o lugar do nascimento e morte, enquanto o Verbo é eterno. No capitulo 10, aprofundando ainda mais a questão da eternidade supratemporal do Criador e o caráter temporal da criatura, o futuro Bispo de Hipona se indagará acerca da ocupação de Deus antes de criar o céu e a terra e responde: Ele era ocioso e nada fazia. Desta resposta decorre, consequentemente, outra pergunta: "Por que não permaneceu então sempre ocioso e daí por diante sem nada fazer, abstendo-se de toda criação?” (Conf. XI, 10) Da resposta em forma de pergunta, seguem outras indagações até culminar numa importante questão: se a vontade de Deus é eterna, por que também não é a da criatura? E, no capítulo 14, em continuidade, afirma: "Não houve nenhum tempo em que não fizésseis alguma coisa, pois fazíeis o próprio tempo. Nenhum tempo Vos és coeterno, porque Vós permaneceis imutável, e se os tempos assim permanecem, já não seriam tempos" (Conf. XI,14). Eis que surge então a decisiva questão: O que é então o tempo? (Quid sit enim tempus?) Quem poderá explicá-lo clara e brevemente? Quem o poderá apreender, mesmo que só com o pensamento? Agostinho, de certa maneira seguindo Aristóteles ${ }^{6}$, aponta a própria dificuldade de se falar sobre o tempo, "como

\footnotetext{
${ }^{6}$ Aristóteles, na Física IV, 10, 217 b à 218 b, indica algumas dificuldades para se falar e definir o tempo.
} 
aquilo que sei o que é, mas se me perguntam já não sei” (si nemo a me quaerat, scio, si quaerenti explicare velim, nescio. Conf. XI, 14). Ele fala sobre o tempo como sentido interno, portanto, um tempo psicológico, que se passa na alma e, por isso, não ontológico, pois, o tempo não é em-si mesmo: ele não é pretérito, pois o passado já passou, não é mais; nem é futuro, pois este ainda não é, será; e caso fosse só presente, seria eterno e, consequentemente, não seria mais temporal. O tempo, então, para Agostinho se manifesta internamente n'alma, sendo nesta que a sua mensurabilidade é estabelecida como pretérito, presente e futuro, tal como é apresentado nos capítulos 15, 16 e 17. No capítulo 17, ele usa ainda os termos narrar e vaticinar, para indicar que a experiência nos mostra que há o futuro e o passado, ou seja, que há fatos futuros e passados. A reflexão sobre a criação do mundo e a relação entre o Verbo criador e o tempo que se instaura na e pela criação conduzem-no à questão da passagem do tempo e de sua divisão em pretérito, presente e futuro; quando, a partir destas questões, se pergunta pela possibilidade de se pensar essa divisão do tempo, e, precisamente, argumentando pela existência de "fatos passados", ele diz: "E os que narraram fatos passados, sem dúvida não os poderiam veridicamente contar, se não os ouvissem com a alma” (Conf. $\mathrm{XI}, 17$ ) - o mesmo se pode dizer dos que vaticinam o futuro. Por isso que, para Agostinho interrogar-se sobre o tempo é o mesmo, em certa medida, que se interrogar sobre o eu narrador - ser temporal que vive e morre no tempo - e sobre o sentido da própria narração. Destacamos a sua referência à atividade de narrar fatos passados que se constituem como aquela atividade em que o que já não existe mais retorna à luz (abstraindonos, em princípio, do modo como ele, não mais existindo pode ser "visto" com a alma).

No capítulo 18, Agostinho se dispõe a resolver as dificuldades que o tema lhe impõe. Ele diz sobre o futuro e o passado "quero saber onde estão”. O problema começa a ser solucionado quando ele intui que, se passado e futuro existem, eles só podem existir no presente, por exemplo, lembrar o que passou, qualquer que seja o conteúdo do que é lembrado, ele só pode ser no presente. A memória não relata os acontecimentos, mas as palavras concebidas pelas imagens dos fatos que, ao passarem pelos sentidos, registraram seus vestígios no espírito. A recordação do passado, portanto, é uma representificação. A segunda parte do capítulo 18 mostra como a espera do futuro acaba sendo uma espécie de presente, o limiar no 
qual a é apresentado o problema, é o da profecia. A estrutura do pensamento é a mesma da investigação do passado. Quando vaticinamos, só podemos ver coisas que existem. Então o que já é, não pode ser futuro e nós não vemos os fatos futuros, mas suas causas ou seus prognósticos já dotados de existência. Portanto, só podemos prever o futuro a partir da lembrança presente das coisas passadas, ou seja, são as imagens contidas na memória e não as coisas futuras elas mesmas que nos permitem prever o futuro. O que se deixa ver, talvez, são as causas e as imagens do que já existe. O que vemos em nossa frente não são as coisas futuras - pois o que é futuro, ainda não é - mas se não podemos prever o futuro é porque vemos o passado, e com ele, pelos vestígios impressos na alma, podemos prever o que há de ser, não por conhecermos algo que ainda não é em si mesmo, mas por sabermos conhecê-lo em sua causa. Pois todo saber se constitui pela memória. Santo Agostinho toma como exemplo uma situação ordinária do cotidiano. "Vejo a aurora e prognostico que o sol vai nascer. Não é o sol que é futuro, porque ele já existe, mas sim seu nascimento que ainda não se realizou" (Conf. XI, 18). Entretanto nem a aurora nem a imagem em meu espírito é o nascimento do sol, mesmo que tenhamos que enxergar a aurora e a sua imagem como presente.

O capítulo 19 é apresentado em uma estrutura de uma oração, ao Senhor do futuro. No capítulo 20 são recapitulados sinopticamente os resultados até então obtidos e é, decisivamente, declarado que o passado e o futuro são apenas em relação à atitude que a alma tem diante do Tempo. Agostinho ainda acaba por dar contornos bem claros a todo questionamento sobre os três níveis do tempo, ao dizer que há três tempos: um presente do passado, um presente do presente e um presente do futuro - é neste sentido que deve ser pensada a linearidade do tempo em oposição à visão linear cronológica. Mas como se manifestam essas três dimensões?7 Nosso filósofo responde que no presente, ela se manifesta no percebido, no passado, naquilo que é contido ou recordado e, no futuro naquilo que é esperado. Percebe-se que a terminologia agostiniana, nesta altura do argumento, é muito mais precisa do que noutras passagens. Ele chega mesmo a dizer que não importa muito que as palavras tenham que dizer tudo das coisas, pois, poucas são as coisas que exprimimos com uma

\footnotetext{
${ }^{7}$ Segundo Paul Ricoeur: "os três desígnios temporais dissociam-se na medida em que a atividade intencional tem como contrapartida a passividade engendrada por esta própria atividade”. (RICOEUR, Paul. Tempo e Narrativa. Tomo I. P. 40).
} 
linguagem exata. Portanto, segundo o Santo Doutor, há um abuso no uso da linguagem quando dizemos existir três tempos: passado, presente e futuro. O que de fato ocorre é certa presença na alma (de um tríplice presente): "o presente do passado, a memória; o presente do presente, a visão presente; o presente do futuro, expectativa”.

Com essa reflexão acerca da linguagem que nem sempre é exata, mas pode fazer entender o que ela expressa, Santo Agostinho termina a primeira parte da investigação sobre a existência do tempo.

Nos capítulos de 21 à 28 temos a parte que trata da essência do tempo. O nosso filósofo retoma a questão da possibilidade de se medir o tempo, colocando-a novamente em estado de aporia, em razão de medirmos o que não existe (as coisas pretéritas e futuras). Além disso, se medirmos o tempo presente, sua extensão é tão fugidia que não a captamos. Agostinho, então, faz novo questionamento sobre a origem do tempo, mostrando que ele se origina do futuro, passa pelo presente e se dirige ao passado e conclui que ele: "nasce daquilo que não existe, atravessando o que não tem dimensão, para ir para aquilo que já não existe" (Conf. XI, 21).

O capítulo 22 é, em sua maior parte, também, uma oração dirigida a Deus, por uma alma aflita diante do enigma do tempo. Aqui, o exemplo tomado é da experiência natural, pois falamos do tempo constantemente: "por quanto tempo falou este homem? quanto tempo se demorou em fazer isso? há muito tempo que não vejo aquilo, esta sílaba longa tem o dobro do tempo daquela sílaba breve" (Conf. XI, 22). Agostinho sabe que todos compreendem essas palavras que são muito claras e muito ordinárias. Para o pensamento filosófico que investiga, agora, a essência do tempo, as palavras são muito obscuras.

Agostinho volta a seguir, a questionar aspectos relativos à essência do tempo. O que procura nosso autor, a essa altura, é a necessidade de solucionar o enigma do tempo, parece haver uma tentativa estabelecê-lo como análogo ao movimento dos astros, posição bastante próxima a já apresentada por Eratóstenes de Cirene (276 a.C.-194 a.C.), para quem "o tempo é o curso do sol”. No entanto, questiona o futuro Bispo de Hipona, se o tempo fosse o movimento dos astros, como poderia se mover no tempo a pedra do oleiro? Então vemos que o movimento dos corpos não é no tempo, mas serve para a sua determinação estendida em dias e anos. Agostinho mostra, portanto, que o que experimentamos na extensão de 
dias e anos não é uma característica do movimento do sol. O tempo empresta ao movimento dos corpos celestes sua extensão, de modo que eles possam ser experimentados. E, por isso, o tempo não é idêntico ao movimento dos astros, mas este é um movimento intratemporal. O santo filósofo diz ainda "que quer conhecer a força e a natureza do tempo com que medimos o movimento dos corpos” (Conf. XI, 23) que equivalem aqui a sua essência. Daí, se pode formular a questão: Qual é a constituição essencial do tempo que confere duração ao movimento solar que pode ser medido? E bem no final do capítulo 23, nosso filósofo dá a primeira indicação da essência do tempo, quando afirma que o tempo "é uma distensão.”

Nos capítulos subsequentes, Agostinho se esforça para mostrar isso. No Capítulo 24, ele retoma, reformulando, à questão da identificação do tempo com o movimento dos corpos, negando que ele seja tal movimento, entretanto afirmando que este se dá no tempo. É necessário para se falar em medida de tempo, que se tematize e a percepção que se tem do corpo que se movimenta, pois, afinal, ela só pode receber uma parte de tal movimento. No capítulo 25, retoma a constatação da ignorância sobre o tempo, "quid sit tempus". Todavia, pode se notar que pouco a pouco, de aporia à aporia, uma delimitação da essência do tempo vai se assentando. Agostinho mostra que quando digo não saber nada sobre o tempo, é no tempo que eu digo, e enquanto digo, o tempo já se estendeu. No entanto, eu não sei ainda o que é o tempo. No capítulo 26 enfim, se chega à concepção de tempo como distensão da alma. Para se chegar, no entanto, a tal concepção, Agostinho retoma a questão da mensurabilidade, mostrando que a medida do tempo em mais longo e mais breve é diferente da medida com que meço um côncavo. O exemplo que possibilita Agostinho chegar ao resultado final é o da medida da duração de uma sílaba. Temos critérios diferentes para medir: com um deles se mede o espaço; com outro, a extensão temporal. Acontece, porém, algo de decisivo para a determinação da essência do tempo, a saber, que é possível se tomar a medida de uma sílaba e alongando-a ou encurtando-a. A partir dessa constatação, Agostinho dirá, categoricamente, que o tempo não pode ser outra coisa senão que uma distensão. Ao chegar a esse ponto central do seu pensamento, santo Agostinho parece ainda oscilar entre conhecer e não conhecer a natureza do tempo e diz, inicialmente, que não sabe do que ele é distensão. Logo em seguida, afirma que se admiraria se ele não fosse 
distensão da própria alma. A experiência de mim mesmo, pela qual possa estender ou encurtar a duração das sílabas pronunciadas no verso, garante o tempo é a distensão dos movimentos (de ir e vir) da alma humana (Distentio Animi) e é nessa distensão que ele (o tempo) é compreendido como tempo.

Tendo resolvido a questão da essência do tempo, no capítulo seguinte se procura responder à questão de como o tempo se estende. Agostinho usará o exemplo do soar de um verso ou de uma canção. A voz que ecoa antes de começar a ecoar estava no futuro e não podia ser medida. Depois de ecoada, era passado e também não podia ser medida. Do mesmo modo, uma voz que ecoa indefinidamente só pode ser medida; se não a meço enquanto ecoa, não a posso mais medir. No entanto, medir significa captar a duração entre o seu começo e o seu fim, precisando, pois, esperar que ela chegue ao fim para medir. Mas então, ela já é passado e não pode mais ser medida. Agostinho exemplifica melhor isso ao propor a medida de uma sílaba longa com uma sílaba breve. Eu não as posso medir porque, do seu surgimento ao seu fim houve um processo que levou ao não-ser. Então surge a questão sobre o que eu meço. Não são as sílabas, porque elas não mais existem. Finalmente, Agostinho dirá que é na alma que se mede os tempos. E para conceder uma unidade essencial a todo processo de distensão da alma, nosso filósofo dirá que as três dimensões do tempo permanecem em seu estatuto essencial, quando, de um lado, temos o futuro como esperança-expectativa da alma no presente; o presente como atenção-cuidado da alma no presente; o passado como memória-recordação da alma no presente.

O tempo compreendido como a distensão dos movimentos no interior da alma que lhe garante a continuidade real, em as Confissões, será projetado à história, em $A$ Cidade de Deus ${ }^{8}$, constituindo-se, por assim dizer, como o seu próprio sentido, permitindo, deste modo, compreender a sua mudança através da mensurabilidade linear sucessiva em relação ao passado, presente e futuro. Esta forma linear sucessiva e interna do tempo relacionada ao movimento que contrasta com a clássica concepção genérica circular grega sem início e se fim. Por isso, segundo ele, o tempo foi criado simultaneamente com o mundo e, por conseguinte,

\footnotetext{
${ }^{8}$ Cf. a distinção entre o tempo e a eternidade em suas relações com a mudança e a imutabilidade em $A$ Cidade de Deus, XI, 6. Esta passagem é de suma importância para um estabelecimento da relação entre a teologia do eu, nas Confissões e a teologia da história em A Cidade de Deus.
} 
a temporalidade é una, os acontecimentos só têm sentido devido à criação9 . Os acontecimentos isolados dos povos, por sua vez, só têm sentido se estiverem relacionados dentro do todo, ou seja, com totum genus humanum. Além da criação, existem outros fatores que são relevantes para que os acontecimentos tenham sentido: a redenção da humanidade por Cristo e o fim dos tempos com o seu retorno, no juízo final. A concepção cíclica grega tanto cosmológica quanto política - quer dizer tanto da natureza quanto da polis - é vista pelo cristianismo, de modo geral, como uma desesperança, porque a esperança e a fé se referem essencialmente ao futuro e este não poderia existir se os tempos passados e os vindouros fossem do mesmo ciclo, sem começo e sem fim. Com o cristianismo, portanto, o tempo se articula linearmente em passado, presente e futuro. O presente se liga ao passado pela morte e ressurreição de Cristo e ao futuro pela salvação e a consumação.

\section{A origem e a tensão entre as duas cidades: a de Deus e a dos ímpios}

Depois de termos analisado a linearidade tensa do sentido interno do tempo na alma estabelecida nas Confissões e a peculiaridade da ideia de progresso decorrente, que segundo a nossa hipótese hermenêutica, é um dos pressupostos para se compreender a sua reflexão teológica sobre a história, faltam analisarmos, ainda, em A Cidade de Deus, os outros dois pressupostos que são necessários para a compreensão dessa Teologia da História, a saber: "a origem e a distinção tensa entre as duas cidades" e "os seus desenvolvimentos e fins", tal como o próprio autor propõe nos livros que vão de XI a XXII. O Bispo de Hipona, remissivamente, descreveu, sobre A Cidade de Deus, na obra Retractationes, em 428, as razões que lhe compeliram a escrever esta "imensa e árdua obra", o objetivo e conteúdo inicial foi à tentativa de conciliar o conflito entre a fé e a história, abalados pelo saque de Roma, em 410, ${ }^{10}$ pelo rei visigodo Alarico.

\footnotetext{
Naquele tempo, Roma foi invadida pelos godos, sob o comando do rei Alarico; e ela foi quase destruída pelo desastre desta memorável derrota. Este desastre, os adoradores da multidão de falsos deuses que chamamos em linguagem ordinária de pagãos, se esforçaram em atribuir à religião
}

${ }^{9} \mathrm{Cf}$. A Cidade de Deus, XI, 6.

${ }^{10}$ Retractationes, Livro II, Cap. XLIII. Cf. 
cristã e começaram a blasfemar, com mais amargura e mais do que nunca contra o verdadeiro Deus. Inflamado pelo zelo da casa do Senhor, comecei a escrever contra seus erros ou suas blasfêmias, os livros de A Cidade de Deus. (Retractationes, Livro II, Cap. XLIII).

Agostinho já havia apresentado no prólogo ao Livro I, da A Cidade de Deus, o objetivo eclesiástico que lhe havia motivado a escrever o tratado: "A gloriosa A Cidade de Deus. [...] obra que estou escrevendo [...], e empreendo defendê-la contra esses homens que preferem seus próprios deuses ao fundador desta cidade. Trata-se de uma obra imensa e árdua, mas conto com auxílio de Deus"11.

Seguindo, portanto, o esquema fornecido pelo próprio autor em Retractationes, pois é onde melhor são expostos, sinteticamente, os objetivos da obra, A Cidade de Deus tem sido tradicionalmente dividida em duas partes e essas, por sua vez, subdivididas em cinco subpartes. Nas duas primeiras subpartes da primeira parte é argumentado que: a adoração dos deuses não pode proporcionar felicidade nesta vida (livros IV) ou na próxima vida (livros VI-X); as três subpartes seguintes que compõe a segunda parte se referem, respectivamente, às origens (livros XI-XIV), ao desenvolvimento (livros XV-XVIII), e aos fins (livros XIX-XXII) das duas cidades ${ }^{12}$.

Ainda que, o Santo Doutor se refira, por diversas vezes, às "duas cidades" no conjunto da sua obra ${ }^{13}$, abrangendo os dez primeiros livros que compõem $A$ Cidade de Deus, será apenas a partir do livro XI até o XXII desta, que ele definirá a origem, o desenvolvimento, a natureza e os fins das "duas cidades". Agostinho inicia, então, a segunda parte (livro XI, 1), estabelecendo uma distinção na origem entre as duas Cidades, a de Deus e a dos ímpios - embora não mencione ainda o homem como sendo o

\footnotetext{
${ }^{11}$ A Cidade de Deus, livro I, prólogo. No capítulo I do livro XVIII, Agostinho, recapitulando a obra também, descreve sinopticamente a ordem esquemática da sua reflexão ao longo do tratado, porém de maneira menos abrangente do que o esquema de Retractationes.

${ }^{12}$ Cf. Retractationes, Livro II, Cap. XLIII.

${ }^{13}$ Antes d'A Cidade de Deus, Agostinho já mencionava a existência de "duas cidades" que decorrem das suas leituras bíblicas e, sobretudo, as do Apóstolo Paulo. Em Sobre a Verdadeira Religião, fala de "duas bandas” (De vera rel. 37, 50); em Sobre o Modo de Catequizar os Simples, fala em “duas cidades” (De catechizandis rudibus, 20, 31); em Sobre o Gênesis ao Pé da letra (De gen, ad litt., XI, 15, 20) e em Sobre o Gênesis Contra Maniqueus (De Genesi Contra Manichaeos, II) o seu autor divide a humanidade em dois gêneros de comunidades, fundamentadas em dois tipos de interesses ou amores, tal qual aparecerá anos mais tarde em A Cidade de Deus (livro XV, 1); em Comentário aos Salmos, CXLVIII, escrita por volta de 395, Agostinho estabelece a distinção entre as "duas cidades", simbolicamente, representadas por Jerusalém e a Babilônia.
} 
responsável, devido a sua livre escolha, pela Cidade terrena -, tal distinção é o ponto de partida para compreendermos a sua reflexão sobre a história teológica, compreendida como a história da salvação:

Por esses e outros testemunhos que seria prolixo enumerarem, damo-nos
conta da existência da Cidade de Deus, de que, pelo amor que nos inspirou
o seu Fundador, aspiramos ser cidadãos [...] e a dos ímpios e soberbos,
que, privados da luz imutável e comum a todos e reduzidos, por isso, à
miserável poder, pretendem senhorios de certo modo privados e de seus
enganados súditos buscam honras divinas. (Livro, XI, 1)

Agostinho, neste primeiro momento, portanto, relaciona a origem da Cidade de Deus com o ato da criação dos anjos por parte de Deus e a origem da Cidade ímpia com a queda dos mesmos, diz ele, sobretudo, com base no livro Gênesis: "No princípio [...] Deus estabeleceu uma divisão entre a Cidade de Deus, que não peregrina nesta mortalidade, mas é eternamente imortal, quer dizer, entre os santos anjos, que se encontram unidos em Deus e não desertaram nem desertarão, e os que, ao abandonarem a luz eterna, se tornaram trevas" (livro XI, 28). ${ }^{15} \mathrm{E}$ na sequência afirma: "alguns anjos pecaram e foram recaídos nos abismos deste mundo, cárceres para eles, até à condenação final e futura no dia do juízo" (livro XI, 33). Tudo indica, até aqui, que a origem das "duas cidades” antecede à criação do homem, surgindo uma na criação dos santos anjos por parte de Deus - a Cidade de Deus - e a outra, na rebeldia dos anjos - a Cidade ímpia. Trata-se, portanto, de "duas cidades" de natureza mística, que têm como princípio de fundamentação a distinção estabelecida entre o bem e mal, herança maniqueísta de Agostinho em estreita relação com a doutrina do livre-arbítrio, sem, no entanto, até o início do XII, se referir à criação do homem e a sua queda, ele fala apenas sobre a natureza dos anjos bons e maus. ${ }^{16}$

\footnotetext{
${ }^{14}$ Fórmula semelhante é apresentada no Livro XIV, 28, ao delinear essas duas cidades: “... duas cidades foram formadas por dois amores: o terreno, por amor de si mesmo e o desprezo por Deus; o celestial, pelo amor de Deus e o desprezo de si próprio.”

${ }^{15}$ As identificações dos anjos bons com a luz e a dos rebeldes com a treva ficam mais reforçadas em A Cidade de Deus, Livro XIX, 11.

${ }^{16} \mathrm{Cf}$. livro XII, 1.
} 
Porém, antes de afirmar com convicção que, o homem foi criado no tempo, em XII, $15^{17}$ e, mais ainda, que Deus o fez nas mesmas condições dos anjos, a saber, constituído de vontade livre, ou seja, de livre-arbítrio, o nosso filósofo passa, consequentemente, no livro XII, nos capítulos que vão de 7 ao 9, mais especificamente, em 8, a relacionar o homem com as origens das "duas cidades". Deste modo, devido ao livre-arbítrio: uns permaneceram em Deus, criando a Cidade dos bons; outros Lhe desobedeceram, criando a Cidade dos maus. Ainda que a doutrina do livrearbítrio tenha uma aparição tímida em $A$ Cidade de Deus ${ }^{18}$, a sua atuação é fundamental para compreendermos a origem e a distinção entre as duas cidades e, por conseguinte, os seus fins - como veremos mais adiante.

A concepção que Santo Agostinho tem dessa doutrina, ele trás de reflexões elaboradas em outras obras, ${ }^{19}$ sobretudo, em De libero arbitrio (388-395), que foi composto em três livros, escrito em forma de diálogo e que começa com a questão, "se Deus seria a origem do mal moral?"2o, posta a ele por seu amigo e conterrâneo, de Tegaste, Evódio. A resposta de Agostinho não deixa nenhuma sombra dúvida: Deus não está na origem do mal, pois Ele é bom por essência e imputar-lhe tal causa, implicaria negar-lhe a própria divindade e, por isso, nos aconselha a voltarmos para os homens e buscar na particularidade de seus atos a causa da mal. ${ }^{21}$ Podese conjecturar de imediato que o mal é algo que os homens aprendem, ao virem no mundo, como pecadores, entretanto, Agostinho rejeita a simplicidade desta primeira formulação, pois, segundo ele, se aprendemos o mal, deveríamos ter aprendido evitá-lo e não a fazê-lo, devido o aprendizado ser um bem, portanto, quando agimos mal estamos nos distanciando da via do aprendizado. ${ }^{22} \mathrm{Na}$ conclusão do livro II do Livre-

\footnotetext{
17 "Devo dizer, sem vacilar, não haver o homem existido antes do tempo e ter o primeiro homem sido criado no tempo" ( A Cidade de Deus, Livro, XII, 15). Esta afirmação, todavia, não nos autoriza a dizer que o tempo precede ao homem ou é algo fora do homem, dado que como vimos acima, o tempo é antes de tudo em Agostinho psicológico, ou seja, é uma concepção interna, imanente à alma.

${ }^{18}$ Em A Cidade de Deus, o tema aparece mais evidente em: livro V, 8, 9, 10; livro XII, 7, 8, 9; livro XV, 22.

${ }^{19}$ Cf. sobre o livre-abítrio em Santo Agostinho, principalmente: De libero arbítrio (391-395); De gratia et libero arbitrio (419), obra posterior à publicação de A Cidade de Deus. Entretanto, podemos ver a gêneses do livre-abítrio na ideia bíblica de que a liberdade é uma dádiva de Deus que nos fez a sua imagem e semelhança nos equipando com esta doutrina. Cf. como uma pré-formulação da doutrina em alguns textos bíblicos conjugados: Gen. 1:26, MT 22:37, Provérbios 16:9, Deuteronômio 30:19-20.

${ }^{20}$ De lib. arb. I, intr., cap.1., 1. "Peço-te que me digas, será Deus o autor do mal?”

${ }^{21}$ Cf. Ibid.

${ }^{22}$ Cf. De lib. arb. I, Intr., cap. 1., 2, 3 e Cap. 2., 4
} 
Arbítrio (cap. 20, 54), Agostinho define o mal como sendo a ausência de Deus. Essa ausência decorre devido o homem ter escolhido um caminho que o afasta do bem, uma vez que o mal não pode vir de Deus. Surge, deste modo, a ideia de livre-arbítrio como aquilo que confere ao ser humano a vontade livre de decidir seguir outro caminho. Então, a fonte do mal é o próprio ser humano, que, por livre decisão, se afasta de Deus e, consequentemente, gera o mal.

A dicotomia entre o bem e o mal - presente nas reflexões de Agostinho - que preparou o terreno para a formulação de dois conceitos que estruturam a noção de livre-arbítrio, a retidão e o pecado que consequentemente serão depois em A Cidade de Deus as causas do conflito entre as duas cidades. A retidão consiste na submissão das paixões à razão e o pecado, por sua vez, é o inverso, ou seja, consiste na submissão da razão às paixões, gerando o insensato. A causa do pecado é a vontade livre decorrente do livre-arbítrio, uma vez que nada força a razão a se submeter às paixões, nem esta à razão. Por isso, só quem tem o livre-arbítrio pode $\operatorname{pecar}^{23}$.

Um problema surge, entretanto, em decorrência do livre-arbítrio ser a origem do mal no mundo, a saber: por que Deus o doou ao ser humano e também aos anjos? Se não houvesse tal doutrina, não haveria, portanto, o pecado. Não se trata, todavia, da pretensão inicial de Agostinho, que procurava, antes, afastar ideia que Deus pudesse ser a fonte do mal, e em resposta a este problema, ele diz que o livre-arbítrio é um bem e um dom divino. Como exemplo, ele nos dá a visão, que é um dom divino que nos permite enxergar, mas não é porque se pode pecar por meio dos olhos que Deus não deveria ter nos equipado com eles. Por causa do livre-arbítrio, o insensato, cuja mente é dominada pelas paixões, pode, com justiça, ser castigado por ter feito um mau uso deste dom $^{24}$. Por conseguinte, sem o livre-arbítrio, não existiria nem a justiça nem a retidão e de nada adiantaria louvar os corretos e censurar os maus. O problema do livre-arbítrio, então, está em se fazer o mau uso deste, e não, de condenar Deus por tê-lo concedido aos homens. Em tese, segundo Agostinho, o homem tem a possibilidade de não pecar e o poder de decidir

\footnotetext{
${ }^{23}$ Cf. De lib. arb. de I, 1: cap. 3., 6 à I, 2: cap. 7., 16 e 17.

${ }^{24}$ Cf. De lib. arb. II, intr., cap. 1., 3.
} 
se quer ou não pecar. É nesse sentido que se deve compreender o livrearbítrio como causa do pecado.

Estabelecido que a causa do pecado é o livre-arbítrio, surge a necessidade de se saber o que é e o que não é pecado. Por isso, Agostinho lança mais uma dicotomia entre a lei eterna e a lei temporal. A lei eterna é a razão suprema de tudo, à qual é preciso obedecer sempre e em virtude da qual os seres humanos bons merecem uma vida feliz, e os maus, uma vida infeliz ${ }^{25}$. A lei eterna ordena ao homem que se desapegue do amor pelas coisas temporais e que se volte para as coisas eternas, espirituais, que conduzem à beatitude. Por ser a razão suprema, esta lei é a Verdade e a verdadeira liberdade consiste em segui-la. A Verdade está na mente humana, isto é, na razão, pois é por meio desta que se descobre aquela. Portanto, para Santo Agostinho, a nossa liberdade consiste em estar submetido à Verdade. Essa Verdade é o nosso Deus mesmo, o qual nos liberta do mal, da condição do pecado. Já a lei temporal é aquela que pode ser alterada com o passar do tempo e que protege o ser humano em relação às coisas temporais, a fim de salvaguardar a paz e a ordem na sociedade ${ }^{26}$. O castigo da lei temporal consiste em interditar e privar os seres humanos das coisas temporais. Ela não pune o apego demasiado a essas coisas temporais; apenas pune quem os subtrai injustamente de outrem. Quando questionado sobre os impulsos que levam o homem a agir diferentemente do que gostaria de agir, Agostinho sustenta que, embora o homem seja livre para pecar ou ter uma vida reta, essa possibilidade de pecar vem do hábito. Santo Agostinho distingue, pois, o conceito de liberdade do conceito de livre-arbítrio ${ }^{27}$. A liberdade (libertas) designa o estado de beatitude etern $\mathrm{a}^{28}$ no qual não se pode pecar, diferenciando-se assim da possibilidade do bem ou mal voluntários. O livre-arbítrio, ao contrário, designa a possibilidade de escolha entre o bem e mal.

\footnotetext{
${ }^{25}$ Cf. De lib. arb. de I, 1: cap. 6., 15.

${ }^{26}$ Cf. De lib. arb. de I, 3: cap. 15, 31.

${ }^{27}$ Cf. sobre a distinção entre os conceitos de liberdade e de livre-arbítrio: GILSON, E. Introdução ao Estudo de Santo Agostinho. São Paulo: Ed. Paulus e Discurso Editorial, 2007. Pp. 271-314 BIGNOTTO, Newton. O conflito das liberdades: Santo Agostinho. Síntese Nova fase. Belo Horizonte, v. 19, n. 58, 1992.

${ }^{28}$ Depois, sobretudo, em De gratia et libero arbitrio (419), Santo Agostinho relaciona este estado de beatitude com a graça divina que, segundo ele, remissivamente, em Retractationes (Livro I, cap. IX), na parte que faz a revisão do De libero arbítrio, justifica-se aí, nestes termos: "Quanto a graça pela qual Deus predestinou os seus escolhidos e prepara as vontades daqueles entre os quais os que já desfrutam do seu livre-arbítrio, este ponto não foi tratado nesses livros, a questão não foi necessária.”
} 
Portanto, quando os homens se juntaram aos anjos e com eles fundaram as comunidades dos bons e dos maus, pois, na verdade, não há uma separação entre as cidades dos anjos e as dos homens, pelo contrário, trata-se das mesmas "cidades místicas” ${ }^{29}$ do bem e do mal, como o próprio filósofo descreve,

[...] não há inconveniência ou incompatibilidade entre a comunidade dos homens e a dos anjos e, assim, não existem realmente quatro cidades ou comunidades, duas humanas e duas angelicais, mas apenas duas cidades ou comunidades de bons e maus, homens ou anjos. [...] enquanto uns se mantiveram no bem, comum a todos, que é para eles o próprio Deus, e em sua eternidade, verdade e caridade, os outros, embriagados por seu próprio poder, como se fossem seu próprio bem, declinaram do bem beatífico, superior e comum a todos, aos seus particulares. (Livro XII,1)

Não se trata, contudo, de duas cidades distintas, mas de uma variação da mesma, fundadas pelos anjos e homens, ou seja, pelo bem e mal presentes no livre-arbítrio deles, tal como descreve no livro XIII ${ }^{30}$. Nessa perspectiva, Cidade de Deus (civitas Dei) e Cidade Celestial (civitas coelestis) são idênticas, ambas são de mesma natureza mística, marca do neoplatonismo de Agostinho fundamentada na ideia especulativa de bem, cuja fonte é o próprio Bem Supremo platônico, revisado e relacionado ao Deus cristão, que perpassa os atos da vontade humana. O termo Cidade de Deus, por conseguinte, designa a Cidade Celestial, enquanto bem errante na terra à espera do verdadeiro Bem, o Deus eterno e celestial. A Cidade dos ímpios, por sua vez, se identifica com a Cidade terrena (civitas terrena), ambas não passam de uma mesma natureza "mística", enquanto conceito especulativo do mal que perpassa os atos decorrentes da vontade livre humana e angelical. Mesmo quando Agostinho fala das "duas cidades” como cidades dos homens concretos, como por exemplo:

[...] daí que, sendo tantos e tão grande os povos disseminados por toda terra, [...] não formem senão dois gêneros de comunidade humana, que, conforme as nossas Escrituras, podemos chamar de duas cidades. Uma delas é a dos homens que querem viver segundo a carne, a outra, a dos que querem viver segundo o espírito... (Livro XIV, 1).

\footnotetext{
${ }^{29}$ Cf. Livro XV, 1, d'A Cidade de Deus.

30 "Deus, Autor das naturezas, não dos vícios, criou o homem reto; mas, depravado por sua própria vontade e justamente condenado, gerou seres desordenados e condenados [...]. Por isso, do mau emprego do livre-arbítrio originou-se verdadeira série de desventuras" (Livro XIII, 14).
} 
Todavia, essas designações não passam de sentido figurado ${ }^{31}$ do termo para designar a presença de duas realidades místicas, o bem e o mal, tensionando e permeando as vontades e ações humanas, ou seja, segundo Agostinho, quando: "o homem vive segundo a verdade, não vive segundo ele mesmo, mas segundo Deus, pois Deus foi quem disse: Eu sou a verdade. Quando vive segundo ele mesmo, quer dizer, segundo o homem, não segundo Deus, indubitavelmente vive na mentira” (Livro XIV, 4$)^{32}$. Consequentemente, infere o filósofo: “... dos que vivem segundo a carne e outros segundo o espírito originaram-se as duas cidades diversas e contrárias entre si [...] ou uns vivem segundo o homem e outros segundo Deus" (Ibidem.). E, conclui: "Uma é a comunidade dos homens piedosos e a outra dos homens ímpios, cada qual com os anjos de sua comunidade, nos quais precedeu ali o amor a Deus e aqui o amor a si mesmo". (Livro $\mathrm{XIV}, 13)$.

O próprio Santo Doutor nos alerta que devemos examinar o que significa viver segundo a carne, dado que nenhuma natureza é em si má. Seguindo ao Apóstolo Paulo em sua Carta Gálatas ${ }^{33}$, que diz: "As obras da carne são bem manifestas; são adultérios, fornicações, desonestidades, luxúria, culto aos ídolos, feitiçaria, inimizades...”. E conclui:

Todas essas e outras semelhantes recebem do Doutor dos Gentios, em verdade e em fé, o apelativo de obras da carne, senão porque, segundo a figura literária pela qual se identifica o todo pela parte, sua intenção é dar a entender, com nome de carne, o homem todo. (Livro XIV,2).

Como se pode perceber, não há, portanto, uma separação entre o plano espiritual e o material, entre as cidades dos santos anjos e as cidades dos homens, apenas uma tensão entre ambas. Já no primeiro livro da obra, Agostinho nos advertia que na verdade: "Estas duas cidades estão

\footnotetext{
${ }^{31}$ Cf. GILSON, E. A Evolução da Cidade de Deus. P. 52: "Quando o próprio Agostinho fala de uma 'cidade', é, pois em sentido figurado - ou mesmo, como diz, 'místico' - que semelhante termo deve ser entendido. Há, por um lado, a comunidade, ou cidade, de todos os homens, que amando a Deus em Cristo, são predestinados a reinar eternamente com ele e, por outro lado, há a cidade de todos os homens que, não amando a Deus, são predestinados a sofrer com os demônios um suplício eterno".

${ }^{32}$ Para o Bispo de Hipona, "o homem não se tornou semelhante ao diabo por ter carne, de que o diabo carece, mas por viver segundo si mesmo, quer dizer segundo o homem”. (Livro XIV, 3).

33 Carta do Apóstolo dirigida às Congregações da Galácia. Parte desta carta, em forma de autobiografia, trata da conversão de Paulo e de algumas das suas outras experiências, sobretudo, as referências ao seu padecimento na carne.
} 
emaranhadas neste mundo, e misturadas até o último julgamento efetuar

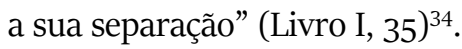

\section{III.O desenvolvimento das duas cidades na progressão temporal e os seus fins}

Passamos a analisar, por fim (nos livros de XV a XXII), o processo de desenvolvimento e os fins das duas cidades, ligando-os à história progressiva da salvação, narrada na perspectiva bíblica da ação dos grandes patriarcas em suas relações de obediência e desobediência a Deus. Este processo vai desde a queda do primeiro homem, Adão, perpassando outros momentos axiais desta trajetória, até o Cristo e deste ao juízo final, em sua missão sagrada de estabelecer escatologicamente a salvação, ancorada numa paz perpétua.

Antes de tudo, temos que dissipar toda e qualquer compreensão de identificação do processo de desenvolvimento das "duas cidades" com a história secular, o que Agostinho tinha para narrar sobre a história, não era como historiador, mas sim, como um teólogo. Em uma passagem, bastante ilustrativa, d'A Cidade de Deus, se referindo aos infortúnios ocorridos com os romanos durante as Guerras Púnicas ( $\underline{264}$ a.C. e $\underline{146}$ a.C.), encontramos uma declaração dele, frequentemente citada, recusando o ofício do historiador, que diz: "[...] se quiséssemos narrar ou mencionar essas calamidades, nos tornaríamos historiadores" (Livro III, 18). Entretanto, para empregar uma expressão do biógrafo irlandês Peter Brow se referindo ao material histórico lido por Agostinho de Hipona, “[...] que tudo isso veio se juntar aos muitos livros de seus contemporâneos que Agostinho intencionalmente ignorou". ${ }^{35}$

Para Santo Agostinho, então, somente no âmbito teológico se pode refletir substancialmente sobre a história universal, compreendida por nós como teologia da história, devido ela ter como propósito a salvação que não pode ser entendida como salvação coletiva, mas senão do indivíduo, enquanto o lócus e foco da graça salvadora de Deus que pode na história de acordo com seu livre-arbítrio se salvar. Por isso, para se falar sobre a história em Agostinho tem de se compreender o que ele entendeu como

\footnotetext{
${ }^{34}$ Cf. sobre a inseparabilidade das duas cidades GILSON, E. Op. cit., 1965, p. 52 e Introdução ao Estudo de Santo Agostinho, p. 332.

${ }^{35}$ Cf. BROWN, Peter. Augustine of Hippo: A Biography. Berkeley: University of California Press, 20oo. p. 294.
} 
tal, por este aspecto, ele só aprovou e praticou três tipos de história. O primeiro foi o da narrativa de conversão ou da história milagrosa que pode ser conferido em as Confissões e no capítulo 8 do livro XXII d'A Cidade de Deus, neste tipo de história pode se ver a graça de Deus atuando sobre as vidas das pessoas para mudá-las e trazê-las à salvação. O segundo tipo foi a da salvação, propriamente dita, que se assemelhava à exegese bíblica literal, e é o tipo praticado na segunda parte d'A Cidade de Deus que compreende os livros de XI à XXII, nestes, Agostinho demonstra como Deus se revelou de forma mais clara através da narrativa bíblica da história sagrada. O terceiro tipo de história praticado por nosso santo filósofo foi o da crônica sincrônica, que põe lado a lado, sincronicamente, a história sagrada e a secular, narrada, especialmente, no livro XVIII d'A Cidade de Deus e recomendada o uso por ele em De doctrina christiana (II, 28). Neste tipo se permitiu que se visse a relação entre a atividade revelada de Deus na história sagrada e a sua atividade oculta na história secular e, ao mesmo tempo, o que ajudava ao entendimento das Escrituras Sagradas. Por isso que para se sentir a presença de Deus diretamente atuando sobre a história, de acordo com Agostinho, é preciso reduzir drasticamente o campo de investigação histórico, pois toda a história secular era vista por ele apenas como uma tentativa humana de criar uma narrativa semelhante a ordenada por Deus.

Neste último tópico de nosso estudo nos deteremos apenas nos dois últimos tipos de história, que são narrados, basicamente, nos livros de XV a XXII d'A Cidade de Deus. Como já dissemos, trata-se de uma releitura do processo de desenvolvimento da história, à luz do Gênesis, compreendida como projeção da concepção linear do tempo imbricado com os conceitos de bem e mal que significam respectivamente a presença de Deus na história (Cidade de Deus) e a desobediência a Ele, por parte dos homens (Cidade terrena). O que temos, portanto, é uma reflexão sobre história da salvação, ou melhor, uma teológica da história - mais condizente com a nossa investigação. A visão agostiniana da "Cidade de Deus" significa a comunidade cristã ou eclesiástica - que deve ser compreendida não institucionalmente - enquanto antecipação do reino Divino, após o juízo final, e que pressupõe uma realização gradual na história em uma longa luta contra o mal oriundo da "Cidade terrena". E, por isso, Agostinho termina o livro XIV, apontando para o desencadeamento sistemático que se dará nos livros de XV adiante: 
No primeiro homem criado tiveram origem, juntamente com o gênero humano, duas sociedades, como que duas cidades. Dele, efetivamente, haviam de proceder a homens destinados a partilhar, uns os suplícios dos anjos maus e outros a recompensa dos bons. E isto por um oculto (mas nem por isso menos justo) juízo de Deus, (Livro XIV, 28)

Em continuidade, Agostinho inicia o livro XV, retomando a distinção já antes estabelecida entre as duas cidades, identificando-as, agora, com mais ênfase, como sociedades de homens, o que nos permite vislumbrar, na obra também, um tratado político teológico, diz ele:

Dividi a humanidade em dois grandes grupos: primeiro, o dos que vivem segundo o homem; o outro, o daqueles que vivem segundo Deus. Misticamente, damos aos dois grupos o nome de cidades, que é o mesmo que dizer sociedades de homens (Livro, XV 1) ${ }^{36}$.

Porém, mais do que dividir a humanidade em dois grupos, a teologia da história de Agostinho pressupõe uma noção hierárquica entre as cidades, sendo uma - a Cidade de Deus -, superior à outra - a terrena -, passando, portanto, a ser aspiração ou ideal almejado pela segunda, dando, assim, um caráter utópico ao modelo de comunidade (Civitas) por ele proposto, o que faz d'A Cidade de Deus, um dos maiores tratados utópicos de política e de história da tradição filosófica. Outro pressuposto implícito na reflexão da história agostiniana refere-se ao fato de que além da Cidade de Deus ser um ideal almejado pela Cidade terrena, esta é anterior àquela historicamente, tanto individualmente falando quanto coletivamente, pois, conforme diz Agostinho, baseado no apóstolo Paulo:

Em cada homem comprovamos a verdade destas palavras do Apóstolo: 'Não é primeiro o espiritual, senão o animal e depois o espiritual. De onde se segue que cada qual, por descender de um tronco danificado, necessariamente é primeiro mal e carnal, e será depois bom e espiritual, renascendo em Cristo'. E isto mesmo sucede na humanidade inteira. Quando as duas cidades empreenderam seu curso evolutivo, por nascimentos e mortes sucessivas, nasceu primeiro o cidadão deste mundo

\footnotetext{
${ }^{36}$ Para George Sabine.: "Santo Agostinho fez desta distinção a chave para compreender a história da humanidade, que está e estará sempre dominada por uma luta entre duas comunidades: de um lado se encontra a cidade terrena, a comunidade fundada nos impulsos terrenos, apetitivos e possessivos da natureza humana inferior; por outro, a Cidade de Deus, comunidade fundada na esperança da paz celestial e a salvação espiritual”. (San Agustín. In: Historia de la teoria politica. P. 148)
} 
430 | Veritas | Porto Alegre, v. 63, n. 2, maio-ago. 2018, p. 408-435

e depois o peregrino do tempo, que pertence à Cidade de Deus (Livro XVIII, 8).

Baseado nesses pressupostos, Agostinho faz uma releitura da história da salvação, projetando sobre ela a sua visão linear e mensurável de tempo, dividindo-a em sete períodos ou épocas correspondentes aos seis dias da criação mais o descanso sabático, tal como foi estabelecido no Gênesis, ou às sete idades do homem, tal como são apresentadas, por ele, nas Confissões e no Contra Fausto - obras coetâneas -, ou ainda, idades do mundo como aparece em Sobre a catequese dos principiantes. Essas épocas são apresentadas da seguinte forma: de Adão até Noé que representa a primeira época da humanidade; de Noé a Abraão, a segunda; de Abrão a Davi, a terceira; de Davi ao cativeiro na Babilônia, teríamos a quarta época; do cativeiro na Babilônia ao Cristo se alcança a quinta; do Cristo ao juízo final a sexta época que representa a renovação da humanidade; e, finalmente, como o descanso sabático bíblico, a consumação final após o juízo final, assentada na eternidade, na paz perpétua. Estes períodos, idades ou épocas da história da salvação significam nascimentos e mortes sucessivos das "duas cidades", ou seja, o desenvolvimento conflitante entre ambas no progresso do tempo ou dos séculos. Esta sucessão de etapas ocorrerá até o juízo final, quando acontecerá o triunfo definitivo do bem sobre o mal, da luz sobre as trevas e da Civitas Dei sobre a Civitas diaboli, que corresponde ao sétimo período, não mais terreno, consumando assim, a história da salvação.

As duas primeiras cidades conflitantes no processo de desenvolvimento da história da salvação de Agostinho nascem do pecado original, que significa um ato de apostasia espiritual da visão contemplativa e do amor de Adão, no Éden, por Deus, quebrando, deste modo, a união entre eles. Visto que Deus é a Verdade, a apostasia de Adão para com Ele representa uma queda no erro e na irrealidade. Uma vez que Deus é a unidade, a queda de Adão foi um colapso na divisão e desarmonia e com ele, toda a humanidade também se viu caída. E assim como a alma de Adão foi dividida contra si mesmo pelo pecado, do mesmo modo, todos os homens foram divididos uns contra os outros pelo egoísmo. O primeiro conflito entre o bem e mal na cidade terrena é representado pelos dois primeiros filhos de Adão, Abel e Caim, em decorrência da apostasia. Por isso, diz o filósofo: "[...] o primeiro filho dos dois primeiros pais do gênero humano foi Caim, pertencente à cidade dos homens, e o segundo Abel, 
participante da Cidade de Deus" (Livro XV,1). A inveja de Caim, que teria sido impossível no Éden, gerou o assassinato de Abel em um mundo em que cada indivíduo egocentricamente se torna o seu próprio deus e juiz para estabelecer o critério entre o bem e mal, a verdade e o erro, de acordo com o livre-arbítrio que lhe habita. Contudo, após o assassinato de Abel, Adão gerou um terceiro filho, de nome Set, que foi interpretado como sendo obra da graça divina. Caim e Set deram, consequentemente, continuidade as linhagens a partir da quais se desencadearam as duas primeiras cidades. Caim significa a continuidade do pecado e da morte, Set, por sua vez, representa a ressurreição e renovação, havendo, na interpretação de Agostinho, desta passagem bíblica, certa correlação com o Cristo: "A morte e ressurreição de Cristo estão figuradas naqueles dois homens, em Abel, que significa luto, em Set, seu irmão, igual à ressurreição" (Livro, XV, 18). Os descendentes de Caim ${ }^{37}$ e Set se multiplicaram sobre a terra durante sete gerações, até o fim do primeiro estágio, dando continuidade a luta do bem contra o mal. Santo Agostinho tendo como base o Gênesis, associando à sua doutrina das duas cidades, nos narra concisamente essas gerações: "Caim gerou Enoc e em seu nome fundou uma cidade, a terrena, não peregrina neste mundo, mas apoltronada em sua paz e felicidade temporais [...]. Enoc significa dedicação, pois a cidade terrena está dedicada a este mundo, onde foi fundada e tem o fim que apetece e pretende. Set, por sua vez, gerou Enós, que significa Homem [...] filho da ressurreição, que vive na esperança, que fundou a cidade do bem ou Cidade de Deus, peregrina neste mundo à espera da vida eterna" (Livro XV, 17-18).

Portanto, devido ao mal disseminado em Babilônia, Deus lançou mais uma vez a sua ira, proliferando múltiplas línguas, propagando uma incompreensão entre elas, entretanto, em sua misericórdia, mandou mais um sinal: Abraão, descendente de Héber e Sem, que devido a sua fé e obediência, daria origem a reis e nações, unificando assim os povos (Cf. Gen. 17: 5,6). Em Abraão teríamos, então, uma pausa, seria o fim do segundo estágio das “duas cidades”. Abraão, por promessa de Deus, teve um filho de nome Isaac, o qual teve dois filhos: Jacó e Esaú, que seriam o início do terceiro estágio das "duas cidades". De Jacó nasceu o povo ${ }^{37}$ É bom observar que no Gênesis não é narrada a história cronológica de Caim, apenas no Jubileus ou Gênesis Menor,
que encontramos mais detalhes sobre a sua descendência. 
chamado Israel, e de Esaú nasceram os judeus: "os dois filhos de Isaac, a saber, Esaú e Jacó, figuram dois povos, o dos judeus e o dos cristãos” (Livro XVI, 42).

Da prole de Abraão e Isaac, até a época dos reis, sucederam algumas gerações, até vir Saul, primeiro rei que, por suas maldades, foi vencido e morto e, com ele, toda a descendência da cidade terrena. Portanto, Saul representa o fim do terceiro estágio das duas cidades conflitantes. Contudo, mais uma vez, da misericórdia divina, veio Davi para suceder Saul e dele descenderam quatorze gerações até chegada do Cristo. No interstício entre Davi e o Cristo, ocorreu o quarto estágio com a destruição do templo em Jerusalém e o povo de Deus sendo transportado para o cativeiro na Babilônia e, por lá, vivendo por setenta anos, até ser liberto, retornando à cidade sagrada, na qual se restaura o templo destruído. Consequentemente, do cativeiro ao Cristo teríamos a quinta era das "duas cidades.” E, finalmente, do Cristo ao juízo final se dará o sexto estágio do conflito entre as "duas cidades" quando, depois da vitória do bem sobre o mal, no juízo final, a humanidade alcançará a redenção, ou seja, a salvação que é a "verdadeira felicidade", o descanso final, que corresponde ao sétimo estágio, semelhante ao descanso sabático, depois da criação do mundo em sete dias.

As consecutivas mortes e nascimentos expressos no embate entre as duas cidades representam a queda ou o pecado do homem e a sua ressurreição (o nascimento), símbolo ou prenúncio da ressurreição final, quando haverá a separação ou a vitória definitiva do bem sobre o mal. Enquanto isso não acontece, como já anunciara Agostinho, no início da obra, as duas cidades caminham juntas: "com efeito, ambas as Cidades enlaçam-se e confundem-se nos séculos até que o juízo final as separe”. (Ibidem., I, 35). Portanto, só no término da obra, nos livros que vão de XIX ao XXII, que o filósofo narra os fins das duas cidades, quando é feita a triagem, no juízo final, de cada história individual inserida na história do todo do gênero humano e se sentencia quem se salvará e que se condenará. A história, todavia, em sua complexidade, pois não se trata de uma realidade estática, está sujeita às peripécias e vicissitudes do tempo, por isso, não há uma lei nela, a partir da qual possamos conhecer o futuro, só Deus em sua eterna onisciência é capaz de tal proeza, o homem, em sua singela finitude temporal, move-se às cegas no palco da história, portanto, o final só lhe será conhecido quando soar a sentença do juízo final, quando 
cada um prestará contas e serão os seus feitos passados que o salvarão ou o condenarão, aí, então, ele saberá à qual cidade pertence. A exposição, desses últimos livros da obra, apresenta o desfecho das duas cidades e as felicidades daí decorrentes. Agostinho enfoca, no livro XIX, como as duas cidades se desfecham, e neste processo, simultaneamente, esboça a natureza do bem supremo, revisando as opiniões dos filósofos a respeito, e seus esforços em vão para fazerem para si uma felicidade nesta vida, e, enquanto, oportunamente, os refutam, mostrando o que a paz e a felicidade que pertencem à cidade celestial são agora e no futuro. O livro $\mathrm{XX}$ trata do juízo final e as provas encontradas nas declarações sobre ele nos, Antigo e Novo, Testamentos, este assunto é mantido por Agostinho, também, ao longo do livro XXI, no qual é descrito, ainda, por sua vez, o fim reservado à Civitas diaboli, ou seja, o castigo eterno dos condenados, advertindo aos leitores da obra sobre descrença que há contra ela, que não se trata, portanto, de um mito. O último livro, XXII, fala do fim da Cidade de Deus, isto é, da felicidade eterna dos santos, a qual, depois, os salvos receberão como recompensa e se tornarão imortais, deste modo, a fé da ressurreição do corpo é estabelecida e explicada. E a obra conclui mostrando como os santos, vestidos em corpos imortais e espirituais, serão dirigidos.

\section{Conclusão}

À guisa de conclusão, Santo Agostinho elaborou, em sua obra Confissões, uma teologia do eu - que não foi objeto direto deste nosso estudo, que só indiretamente, pode ser percebido, devido ao caráter introspectivo do tempo no interior da alma, conduzindo o processo da autossalvação - e, em A Cidade de Deus, uma teologia da história. Ele descobriu, assim, uma ampla explicação da história que começa com uma compreensão interna do tempo, externada para turbulenta e desordenada Cidade terrena e culminando a sua realização, enquanto salvação, na Cidade de Deus. A Cidade de Deus é, por conseguinte, uma conclusão do projeto iniciado em as Confissões, onde ele rastreou o progresso do eu em sua direção para Deus. Da mesma forma, a história e, consequentemente, a sociedade humana se completam no reino de Deus. Podemos perceber que em sua A Cidade de Deus, Agostinho refletiu sobre diversos domínios da investigação filosófica, como a ética e a política, além da teologia e da 
história evidentemente, constituindo uma unidade a partir da universalidade da revelação divina, a história universal, portanto, se completa na lei divina. Contundo, para ele somente as Escrituras podem instruir os seres humanos a agirem a respeito do bem supremo e do mal mais elevado e que, sem essa orientação, o esforço humano não teria nenhum propósito.

A reflexão teológica de Santo Agostinho abre um campo para as filosofias modernas da história, não só àquelas que foram fortemente influenciadas pela providência divina, mas também pelas que concebem o tempo como contínuo e o movimento histórico como progressivo. Contudo, só que essas diferentemente daquelas não admitem mais a providência divina como balizamento último e pré-determinante da história. A partir do século XVIII, os acontecimentos são pensados, em grande parte, em oposição à teologia. A revolução copernicana promulgada por Kant derroca qualquer possibilidade de se fundamentar seja a teoria, a moral, o direito, a política, e a história, a partir de uma autoridade externa, é no limiar da razão e não mais a expressão de uma providência, em última instância, que serve para determinar os acontecimentos humanos.

\section{Referências}

AGOSTINHO, Santo. A Cidade de Deus: contra os pagãos. 9. ed. Tradução de Oscar Paes Leme. Bragança Paulista: Editora Universitária São Francisco, 2006.

. Confissões. 11. ed. Trad. de J. Oliveira Santos e A. Ambrósio de Pina. Porto: Livraria Apostolado da Imprensa, 1984.

. Sobre o Gênesis, contra os Maniqueus. In: Comentário ao Gênesis. Trad. de Agustinho Belmonte. São Paulo: Paulus, 2005. p. 499-591 (Coleção Patrística, n. 21).

. A Trindade. $2^{\mathrm{a}}$ ed. Trad. Agustinho Belmonte. Rev. Nair de Assis Oliveira e H. Dalbosco. São Paulo: Paulus, 1995.

- Oevres Complètes. Bar-le-Duc. Traduites pour la première fois, sous la direction de $M$. Poujoulat et de M. l'abbé Raulx, Bar-le-Duc, 1864-1872. In: http://www.abbaye-saint-benoit.ch/saints/augustin/

ARISTÓTELES. The Complete Works of Aristotle. Ed. Jonathan Barnes In 2 Vol., 6th printing. Princenton, New Jersey: Princeton University Press, 1995. 
BIGNOTTO, N. O conflito das liberdades: Santo Agostinho. Síntese Nova fase. Belo Horizonte, v. 19, n. 58, 1992.

BITTNER, R. “Augustine’s Philosophy of History,” in G. B. Matthews (ed.), The Augustinian Tradition, Philosophical Traditions, [Berkeley: University of California Press, 1999.

BROWN, P. Augustine of Hippo: A Biography. Berkeley: University of California Press, 2000.

GILSON, É. Evolução da cidade de Deus. Traduzido do original, les Metamorphoses de la Cite de Dieu, por João Camilo de Oliveira Torres. São Paulo: Herder, 1965. . Introdução ao Estudo de Santo Agostinho. Trad. Cristiane N. Abbud Ayoud. São Paulo: Ed. Paulus e Discurso Editorial, 2007.

LÖWITH, K. O sentido da história. Trad. De Maria Georgiana Segurado. Lisboa: Edições 70, 1990.

. Histoire et salut. Les pressuposés theologiques de la philosophie de l'histoire. Trad. de Marie-Christine Challiol-Gillet, Sylvie Hurstel, Jean-François Kevérgan, Paris, Gallimard, 2002.

RICOEUR, P. Tempo e Narrativa. Tomo I. Trad. Constança Marcondes César. Campinas, SP: Papirus, 1994.

SABINE, G.. San Agustín. In Historia de la teoria politica. Madrid: Fundo de Cultura Econômica, 1988.

\section{Endereço postal:}

Departamento de Filosofia da UFRRJ, ICHS-DLCS

BR-465, Km 7 Seropédica-Rio de Janeiro, Brasil

Data de recebimento: 16-09-17

Data de aceite: 16-o9-18 